\title{
On the Edge of the Sacred Forest
}

\author{
Guido Sprenger \\ Ruprecht-Karls-Universität Heidelberg \\ sprenger@eth.uni-heidelberg.de
}

Michael R. Dove, The banana tree at the gate: A history of marginal Peoples and global Markets in Borneo. New Haven/London: Yale University Press, 2011, xix + 332 pp., ISBN 9780300153217. Price: USD 55.00 (hardback).

Michael R. Dove, Perry E. Sajise, Amity A. Doolittle (eds.), Beyond the sacred Forest. Complicating conservation in Southeast Asia. Durham: Duke University Press, 2011, xiii + 372 pp. ISBN 9780822347811 , price: USD 94.95 (hardback); ISBN 9780822347965: 26.95 (paperback).

Sarinda Singh, Natural Potency and political Power: Forests and State Authority in contemporary Laos. Honolulu: University of Hawai'i Press, 2012, 224 Pp., ISBN: 9780824835712. Price USD 45.0o (hardback).

It is obvious to say that the relations between human beings and their nonhuman environment are complex, but it is important to draw attention to the way this complexity is modeled and which of the relevant actors and relationships are drawn upon for explanation-in particular when scholars, like the authors of these three volumes, intend to revise and reconceptualise humanenvironment relationships. These relationships are always formed under specific social and political conditions, which these studies aim to elucidate. The question is, which conditions are given more importance and which are less decisive in the models?

Southeast Asia stands out for its great diversity of human-environment interactions, while at the same time its rapidly developing economies create an urgent need to reform and rethink them. These three important contributions to the study of political ecology centre on forests, their globalised and localised uses, the national and transnational claims made in regard to them, as well as the position of those who depend on and live in them.

The three volumes do not shy away from the complexity of the situations they study, in terms of politics, local culture, ecology, history, and transnational

(C) GUIDO SPRENGER, 2014 | DOI: 10.1163/22134379-17002004

This is an open access article distributed under the terms of the Creative Commons

Attribution-Noncommercial 3.o Unported (CC-BY-NC 3.0) License. 
trade, even if policy makers or the public might like to hear simpler answers. But as complexity demands reduction for the sake of developing analytical models, each analysis highlights particular relations and structures. One of the relations underlying most of these studies is the distinction between centres and peripheries. This dichotomy is not only crucial for Southeast Asian polities in their history up to the present, but also for the study of processes of globalisation and localisation worldwide. It works through several codes: in political scales of larger and smaller power centres, villages, and households; as a classification of ethnicities into state-centred and village-based societies; but just as well for the contrast between spaces socialised by human beings and those outside of these, the realm of the forests. The analyses in these three books position themselves at the interface between such codes, by addressing the way that the differences between centres and peripheries shape the relationships between humans and their non-human environment.

The most important relationship this approach highlights is one between central states and their rural peripheries, but the relations between local smallholders and subsistence farmers on the one hand and trade or larger economic actors like estates on the other are also of crucial importance. However, certain other factors which weigh in on the human-environment relationship are hardly elaborated upon here, in particular those of religion, cosmology, or ritual. For many Southeast Asians, processes seen as production from a Western/modern perspective are conditioned by relations with non-humans beings, ranging from the spirit owners of the land to religious ideas about the place of human beings in the world. What seem to be relations of humans with resources, i.e. passive objects, are often treated as relations among human and non-human persons. However, such relations are rarely at the centre of analysis in these books. While the authors seriously aim at a holistic grasp of their fields of study, the models of politics, economy, and ecology which they employ allow little room for local ontologies. I will trace this limitation through the three books, with full respect and often admiration for their other achievements.

\section{State and Forests in Laos}

Sarinda Singh's study, 'Natural potency and political power', explores practices and discourses of forest preservation and state governance in Laos, a poor country with a rich forest cover and nowadays much more a developmentalist than a socialist state. Government politics are secretive and opaque, while laws and regulations are comparatively few. At the same time, Laos joins 
international discourses on environmental protection, not at least in order to attract aid. Still, the discourse on conservation is seen as opposed to development by many Laotians, and international NGOs strategically frame conservation efforts in terms of sustainability. Doing research under such circumstances is extremely difficult, and for this alone, Singh's study merits high praise.

But, as Singh convincingly argues, people still engage critically with their situation. Talking about forests in Laos constitutes a hidden discourse about politics. Two factors enable this: first, forests have always been a matter of politics in the region, although their perception has massively changed. During the pre-colonial period, forests represented the realms beyond the reach of kings and overlords, inhabited by barbaric peoples and dangerous spirits. Forests thus embodied the structural opposite of states and 'civilisation'. However, today the state is considered to be the owner and steward of forests, and this reversal informs the way many locals perceive the state's relation to their environment.

Secondly, in both the older — and still somewhat pertinent—view as well as the new one, states and forests have what Singh aptly describes as 'potential'. Many people in Laos do not consider their state as a system of rules and offices, but as a social network providing different opportunities to different people. The efficiency of the state is dependent upon the role local actors occupy in patronage networks, as well as on foreign-funded projects which support the presence of officials in rural areas. Engaging with the state is unavoidable and might produce positive outcomes, but there is no way of knowing beforehand. In that sense, Singh argues, it resembles the unpredictability of forests. However, Singh tells us comparatively little about the cosmological aspects of the potential of forests and which role it plays in defining sociality for locals. While the argument as such is convincing, one wishes Singh had made more of it, in terms of ethnography, analysis, and theory.

The chapters then highlight some fascinating aspects of forest potency and forest management. Singh shows how the discrepancy between international conservation efforts and Laotian developmentalism has turned into a positive identity marker for Laotians in respect to eating wildlife. In recent decades, eating wildlife has turned from a sign of rural underdevelopment into a luxury for urban dwellers. This development has been facilitated by a general notion of forest potency, as a source of potentially harmful, but also strengthening power that needs to be processed by human sociality.

The underlying figure of complementary social and non-social spaces is embodied in the elephant. Singh analyses the elephant as a symbolically encompassing species whose meat-never eaten-contains thirty-two kinds of 
meat, including human. Through the taming of wild elephants, forest and state were reinforcing each other in their respective potential. Therefore, many Laotians consider forest management as a kind of test for state efficiency, and their relations with the forest are at times indicative of their relations with the state. Forests are thus important targets of state action, in which the state either appears as encroaching upon it as its conceptual opposite or as its owner and protector. This makes the discourse about forests a means to comment on state performance.

From this vantage point, many Laotians see the state failing. Singh documents mismanagement, corruption and excessive logging. In particular, community forest management, the most promising way of managing forests in Laos, is obstructed by state forces which insist on centralised decision making and networks of corruption. Since the book was written, the Laotian government has taken visible steps to curb corruption and increase its protection of forests, but there is still little reason to assume that things have significantly improved. Thus, when locals see the base of their livelihood decline, due to illegal logging for example, their critique is directed against the state-even though not explicitly so. The state, in turn, attempts at veiling its responsibility by a number of uncoordinated strategies, including setting up semi-private companies for the exploitation of forests, blaming 'backward' swidden agriculturalists for forest degradation or criticising foreign conservationists. Singh's analysis is to the point here, in particular as she considers how the 'state' is pieced together from actions, events and intentions.

While taking into account a multitude of different factors and influences, one weakness of the book should not go unmentioned. Although it is based on anthropological fieldwork in Vientiane and the district of Nakai and is sprinkled with references to occasional conversations with villagers, the volume does not convey a sense of place, community or networks. The 'patchwork ethnography' the volume professes to is a difficult genre to master, and it probably demands a firm theoretical and analytical perspective in order to not get out of hand. Readers who want to learn about the way particular communities relate to the forest and to the state as part of their ways of life and everyday talk will come away from this volume slightly disappointed. In other respects, however, this is a rich and engaging book which expertly handles the complexities of human-forest relationships in this part of Asia. As such, it adds substantially to our knowledge of a pressing issue in an under researched country. 


\section{Smallholders and Plantations on Borneo}

Given Michael Dove's long career, it is not surprising that his magisterial volume covers comparable ground with greater depth. Indeed, the way Dove synthesises political and economic perspectives anchored in globalised paradigms with local cosmologies and world orders is masterful. The Banana Tree at the Gate collects essays from the past twenty years. Although quite diverse in method and themes, the chapters effortlessly build an arc around a central theme: the tense relations between local autonomy and global trade in Indonesia. Chapter 2, after the introduction, stands apart from the rest in terms of place and methodology, as it analyses a chronicle of the sultanate of Banjar in eastern Indonesia. Dove skillfully explains the ecology, economy, and politics of pepper production in order to address the destruction of soils, the tensions between pepper producers and middlemen, and the military efforts of the Dutch to control Banjar. At the same time, he introduces the theme, or perhaps more accurately, the morale, of the entire book: The weak and marginalised are hardly ever allowed to control their riches. However, there is no point in isolating them from global processes. Rather, it is crucial to find a balance between external contacts and the insecurities they might bring, and local autonomy.

As Dove goes on to demonstrate, smallholders and in particular rubber farmers found ways of achieving just such a balance, even though it was not permanent. His most prominent model derives from his anthropological work among Kantu in Borneo since 1974. Kantu swiddeners had, at least for a sustained period of time, successfully combined swiddens with rubber cultivation in a dual economy. This allowed them considerable autonomy in the face of changing rubber prices and their own subsistence economy. Rubber could be stored in the trees for a long time when Kantu decided to retreat from the market and focus on subsistence. Retreat from the market was not necessarily driven by low prices - in some cases smallholders responded to market busts by increasing production, as they were always producing for the limited number of their needs which could be satisfied by money. They thus commanded a surprisingly wide range of adaptions to the changing rubber market.

Through a multitude of perspectives Dove elucidates these findings on the politics, history, and mythology of rubber in Southeast Asia. He traces how Hevea trees from Brazil were quickly adopted by Southeast Asians, who had previous experience with collecting tree resins for trade. In one of the most differentiated and in-depth chapters, he explains how and why an alleged dream of a rubber tree predating on rice fields became the focus of millennial concerns for many smallholders on Borneo in the 1930s. Here, he demonstrates 
how the cosmological and the political form a unique and necessary dynamic. Dove counters the obvious interpretation of the dream as an expression of fear of cash cropping and world markets by arguing that it rather signifies the necessity to hold on to a dual economy. The discourses on the dream were thus warnings to keep involvements with markets controlled by locals. Thus, Dove avoids subscribing to arguments by late colonial and independence politics which attempted to restrict Dayak populations in Borneo to rice cultivation. Although these politics aimed at protecting locals from the hazards of the global economy, they ignored that Dayak had been part of world markets for a considerable time and found ways to handle these relationships. The respect and clarity by which Dove explains these local strategies is exemplary and one of the greatest assets of the book. While Dove insists that this dual economy was a product of history and will necessarily become history, his strong argument for its sustainability makes one wonder why it did not turn out more durable.

Part of the answer lies in the pressure from governments and estate holders, which smallholders experienced in an unequal epistemological regime. In particular during the colonial period, smallholders were seen as inferior to plantations, even though they produced more rubber without government subsidies. Dove writes against a common image of smallholders being the recipients of scientific knowledge produced in and for estates. Instead, he contrasts the two production forms as epistemological regimes. Estates transformed the landscape into a new site of knowledge production, governed by modern science. However, quite a number of the features of allegedly scientific estate management were no less symbolic than the rubber tree dream. Clearing plantations from undergrowth was seen as keeping plant diseases away, so that disease outbreaks were blamed on the nearby smallholdings, where undergrowth was kept intact. Only decades later a survey revealed that the smallholdings were healthy. Still, the insight that undergrowth protects rubber trees from diseases was hailed as a 'scientific discovery', when, as Dove surmises, it could just as well been learned from smallholders. Thus, Dove stresses the mutuality of knowledge transfers.

But all this did little to change government and estate attitudes to smallholders. In what is probably the angriest chapter of the book, Dove details the training of plantation managers, by basically reversing the perspective of a research project on estate relations with local workers, which he had conducted in the 1980 s and 1990s. In an ingenious analysis of the manager's culturally trained views, he found ideas about smallholders, workers, and estate management to be still close to the historical patterns. Smallholders and estate workers were cast in the role of those in need of education, as lazy and opportunistic. Conflicts between employers and employees on estates were evaded, either by 
denying the latter a say in their matters or by interpreting them in terms of cultural misunderstandings, when actually power relations where at stake.

The drive behind this book is thus not detached academic curiosity, but a strong commitment to changing perspectives and policies toward smallholders and estate labourers. There is, however, an interesting moment in which Dove-unknowingly? - calls his project partially in question. When he asked the Dayak labourers what they want from estate management, they laughed at the possibility of making demands in the first place. Dove goes on to explain that the Dayak seem to have internalised the hierarchies which mute their voices. This raises the question of anthropological understanding. Is this a case of 'false consciousness', and if so, on which side? Have the Dayak, whose 'fiercely egalitarian values' (p. 234) Dove had invoked a few pages earlier, lost their sense for solving problems on a consensual base? Or is it the anthropologist who underestimates the importance of external hierarchies in which egalitarian societies see themselves embedded into? While Dove notes that the idea of being an overlord contradicts local values, one could argue for many Southeast Asian societies that the egalitarian values which mark relationships among adult community members are elicited by persistent cultural work from an environment which is quintessentially hierarchical. In this respect, one wonders if Dove confused a community-specific egalitarianism among Dayak with the universal and reified egalitarianism of Euro-American political philosophy. But these are mere quibbles with a book which admirably combines a broad range of ethnographic and historical insights with a powerful and convincing agenda.

\section{Which Side of the Sacred Forest?}

The edited volume by Dove, Sajise, and Doolittle represents an interdisciplinary effort covering cases from Indonesia, Malaysia, and the Philippines and is closely related to Dove's authored book. A version of his chapter 7 also appears here, and Endah Sulistyawati's computer modeled analysis of his Kantu data, also published earlier, is found in his references. The book's title, 'Beyond the Sacred Forest', is a bit of a misnomer, but serves well to highlight its limitations. Religious and cosmological factors in the relationship between humans and the environment are hardly considered and never placed centrally in the analysis. The sacred forest of the title simply represents the popular idea that indigenous cosmological practices have conservatory effects. The volume rightly sets out to replace such simplistic notions with more balanced views. However, cosmology in Southeast Asia is to a large extent concerned with the interpretation of what 
a naturalist discourse identifies as the natural environment, and this aspect is given no decisive place in the contributions.

This is not to say that the analyses collected here are reductionist. Their approaches are, in fact, quite varied, and while some are explicitly concerned with conservation, others explore issues of sustainability. One of the outstanding features of the book is a tendency to argue from clearly outlined contradictions and conflicts in the chosen fields, contradictions for which no obvious and ultimate solution is possible. The subtitle, "Complicating Conservation", is thus a mark of distinction, and a well earned one.

Each article links a central contradiction to other factors and, while it allows for advice on policy making, does not pretend to propose any easy solution. This turns out to be an excellent way of modeling complexity. While many contributions start from the distinction between local societies and livelihood on the one hand and state agencies on the other, almost all of them go on to demonstrate that these categories are not homogenous. The local is just as differentiated as the national level, and often in contradictory ways.

Several themes emerge in this volume, highlighting the dimensions of this differentiation. Dove, Sulistyawati, and Jeyamalar Kathirithamby-Wells elaborate on the concept of the dual economy. Sulistyawati demonstrates its effects on wealth and the environment using a computer-based model which traces the development of a combined swidden and rubber economy across seventy years, using different input factors. The model shows the limits of this economy and also that inequalities in wealth will arise with necessity, but also its relative stability. Kathirithamby-Wells comes to conclusions very similar to Dove's in the context of pensinsular Malaysia, in regard to the way smallholders were perceived and treated by government agencies.

A second central concern is ethnicity. Lye Tuck-Po analyses the situation of the Batek, hunters and gatherers in the National Park on the Malay Peninsula. Associating the Batek with nature and the wilderness certainly grows from pejorative local and colonial imagery, but also defines them as part of the nature in the park, thus protecting their lifestyle from government agencies (like the Department of Orang Asli Affairs) which try to sedentarise them. Thus, although both the park's management and the government department share notions of the 'primitiveness' of the Batek, the outcome is contrary. While the park management considers Batek as 'nature' in need of preservation, the Department sees them as 'culture' in need of development. The unresolved conflict between the two positions ultimately protects the Batek way of life, as it remains unclear who is responsible for them.

In her excellent piece on resource use in northern Kalimantan, Emily Harwell analyses an extreme example for the way specific lifestyles and modes of 
sociality shape different relations with the same environment. The landscape in question turns into a wetland with lakes during the rainy season, while the water drains off during the dry months. This makes the landscape an entirely different environment, 'Umwelt' in von Uexküll's sense, for its main inhabitants, swiddening Iban and Malay fishermen. The fishermen concentrate their activities on the months when water is low and live among relatives, when it is high. The Iban live in the area all year and allocate plots of land to community members. While scarce swidden land, which can be carefully divided, is the main resource for the Iban, the Malay depend on the fish whose limitations as a resource they are unable to measure. Swidden plots are used by households and communities, but water is considered as state-owned and therefore commons. Harwell traces the social and cultural implications of these different perceptions of the environment in what is one of the most complex and in-depth contributions to this volume.

A third important dimension of differentiation is land tenure. Both Upik Djalins and Amity Doolittle complicate the dichotomy of indigenous vs. state land tenure systems, by pointing out the diversity of the rules and effects of local tenure systems. For Krui, Indonesia, Djalins shows that indigenous tenure does not equal commons. Rather, land could shift between household and community ownership, thus undermining efforts to formalise local law in terms of state regulations. In a different way, Doolittle demonstrates how a local decision to protect village land by applying for a status as 'native reserve' in the 1950s led to inequalities today. The transition from swidden to vegetable gardens by a number of influential households removes this land permanently from village control. This subverts the idea that the protection of commons protects egalitarian village communities from the introduction of hierarchies by the world market. These examples demonstrate how local relations to the land become simplified on the horizon of state law.

Finally, the state also intrudes in the way local knowledge is valorised and developed. Among the best contributions is Yunita Winarto's epistemologically highly sensitive account of the introduction of the Integrative Pest Management program in Indonesia. After local knowledge was forcefully replaced by Green Revolution packages of seeds, fertilisers, pesticides and technology in the 1970s, pests actually increased, as pesticides killed their natural enemies. Since the 1990s, the Integrated Pest Management supports a shift in the perception of agriculture and its embeddedness in the ecology. Farmers are trained to observe the life cycles of pests and their enemies and thus control them without pesticides. The knowledge developed in this context is local without being traditional. Farmers are empowered again, but the program only spreads slowly, 
the government still supports Green Revolution techniques, and even locals consider these as more efficient during massive pest breakouts.

While the articles are somewhat uneven in their quality, as usual with edited volumes, they contain thoroughly good to excellent work. The authors, together with Singh, represent an important development in research on the environment. By combining knowledge on the ecology with the clear view to political, social and cultural factors, they prove ecological determinism wrong.

Yet, one wonders if cosmological, religious, and ritual approaches to the non-human domains do not run much deeper than the models presented here allow them to. Especially in Southeast Asia, where cosmological and ontological frameworks explicitly encompass forests, fields, water and animals, focusing on politics and economy leaves out an important dimension of analysis. What is ultimately needed is a more thorough synthesis of these perspectives on relations with non-humans, a synthesis that questions the priorities and functional differentiations of modernity and puts them into perspective, as evident in many respects in Dove's work. Of course, the authors are aware of this issue, but the models which most of them employ seem to prevent them from resolving it. Apart from this limitation, these studies are an important step towards revising our understanding of relationships between humans and non-human domains in Southeast Asia, and they provide excellent and clear material for teaching. However, further steps need to follow. We still have to trespass the sacred forest. 